\title{
Interaction of the English Language and Non-Verbal Semiotic Means in the Business Discourse of Creolized Texts on Financial Organizations Corporate Sites
}

\author{
Elena E. Zueva* \\ Higher School of Economics \\ National Research University \\ 25/12 B. Pecherskaya Str., Nizhny Novgorod, \\ 603155, Russia
}

Received 12.01.2016, received in revised form 28.04.2016, accepted 29.10.2016

The article examines the nature of heterogeneous semiotic systems - creolized texts - and their main characteristics. The connection of two semiotic layers in creolized texts - verbal and non-verbal ones is under analysis. The role and interaction of these elements in the text structure is investigated through specific examples - corporate Internet sites of banking organizations. The paper focuses on investigating the correlation of verbal meanings with visually expressed ones and, as a result of the study, offers a classification of the main meanings transmitted by non-verbal elements on the examined sites. The paper aims to extend the knowledge about the pragmatics of creolized texts in business discourse.

Keywords: text, sign, creolized, semiotics, business communication.

DOI: 10.17516/1997-1370-2016-9-12-3044-3053.

Research area: 10.00.00 - филологические науки.

\section{Introduction}

In the last few years there has been an increased interest in applying non-verbal means of communication, so called "visual information" in all spheres of communication. More and more scientists have started to admit the important role played by semiotic means of communication, in particular in mass media and business communication, where it is especially crucial to get the right message across to the potential customer. As a result, many scholars have shifted their focus to the thorough investigation of semiotically complex "non-traditional" video-verbal compound polycode creolized text (E.E. Anisimova, V.M. Beresin, L.S. Bolshiyanova, N.S. Valgina, L.V. Golovina, A.U. Zenkova, O.L. Kamenskaya, V.M.Klyakanov,E.A.Lazareva,N.V.Meshishvilli, O.V. Poimanova, U.A. Sorokin, E.F. Tarasov, L. Bardin, B. Karlavaris, S.D. Sauerbier, etc.).

(C) Siberian Federal University. All rights reserved

* Corresponding author E-mail address: efremova_ee@inbox.ru 
The issue of the comprehensive language study in its diverse connections, including the ones with other semiotic systems, is coming more and more in the foreground in the contemporary semiotic studies. Thus, many researchers remark that "this synthesize whorl in the dialectic spiral of the language studies history was absolutely inevitable. It is connected with linguistics turning to the problem of communication in general, which implies synthesis of the linguistic means of communication with the non-verbal ones, investigation of their organization in a single process and in the text as its result" (Bernatskaya, 2000).

Consequently, the transition to the new scientific paradigm in linguistics at the turn of the $20^{\text {th }}-21^{\text {st }}$ centuries, so called "expansionism" (the term by E.S. Kubryakova) of modern science about the language, encouraged expanding the sphere of the investigated phenomena. The new focus is made on transmission or perception of information in the modern world with a special emphasis on investigating the language in the variety of its links with other semiotic systems.

Another sphere which has attracted much attention recently deals with information visualization. It is worth noting that data visualization has become an inseparable part of modern communication. V.M. Beresin remarks, "Illustration is increasingly becoming an element of text formation. The level of integration of all figures of speech as well as other iconic formations in one textual space of print and electronic editions is rather high" (Beresin, 2003, 162). It is obvious that "the image escalation" does not only mean an absolutely new process of oral communication development, but it also meets the essential needs of the modern society (Kamenskaya, 2002). Therefore, "understanding of the fact, that the modern global world "is focused on the visual way of delivering information resulted in the necessity of singling out the notion of visuality in the context of modern linguistic science" (Zenkova, 2001).

\section{Problem statement}

The purpose of the study is to analyze applications of non-semiotic means of communication in business discourse, and to review their connection with the verbal means of communication. In order to achieve the aim, a comprehensive analysis of randomly chosen 100 financial organizations corporate sites was carried out. The current paper targets at examining the structure of the sites in terms of their verbal/non-verbal components, as well as at defining the main meanings revealed by visual elements.

It is necessary to stress that the issue of investigating verbal and non-verbal components of the creolized texts on corporate web sites is especially acute at present, considering increased significance of the Internet as the means of business communication in the modern world. The research is based on the hypothesis that the strategy of site-makers is determined by the desire to maximize the influence on the addressee and is realized in practice through combining verbal and non-verbal components.

Some specific tasks are going to be achieved throughout the study. The following ones of empirical character are among them:

- to review topic-related information sources by leading researchers in the sphere of semantics and business communication pragmatics;

- to get insights into the specifics of creolized texts.

The practical tasks are the following:

- to investigate the nature of corporate sites of financial organizations

- to measure the share of verbal constituents of the texts and compare them with non-verbal means applied in the same texts; 
- to characterize the interaction of verbal and non-verbal components;

- to identify the role of verbal and visual meanings;

- to single out and group the main non-verbal meanings.

Like many authors, we admit the fact that creolized texts possess a stronger message and communication value than usual texts. Their content is not merely a sum of their components; its complexity emerges as the result of perceiving the verbal text together with its illustration. Consequently, it seems justified to pay close attention to their investigation. So, with this goal, this paper explores the correlation between the verbal and iconic visual semiotic systems, and non-verbal graphic means, which accompany written speech on corporate Internet sites of international financial organizations.

\section{Theoretical framework}

At present, a variety of scientific disciplines, containing the term "visuality" in their name has appeared in the sphere of social and humanities sciences, in particular, visual anthropology, visual culturology, visual politology, visual sociology, theory of visual communications, etc. Much research has already been done in the field of visual communications. Scientists, involved into investigating the phenomenon of visuality, concentrate on the correspondence of oral (verbal) and visual (non-verbal) components, in particular, within print mass media texts (Anisimova, 2003; Boiko, 2006; Bolshuyanova, 1986; Gavrilov, 2006; Lasareva, Gorina, 2003; Chudakova, 2005, etc.).

Growing interest in studying the language in the sphere of its functionality - in interpersonal and mass communication - is generated both by objective laws of scientific methodology approaches development and by the social need to solve vital problems of practical application. Learning functional characteristics of a verbally cohesive text in real communications environment resulted in understanding the fact that in modern communications conditions the natural language is an essential universal means of interaction, however, by far not the only one. Recently there has been an obvious intensity of semiotically heterogeneous texts studies, which in Russian linguistics are traditionally called "creolized texts" both by linguists and psycholinguists in the theory of mass media and its adjacent areas. (M.A. Boiko).

The term "creolized texts" belongs to Russian linguists and psycholinguists U.A. Sorokin and E.F. Tarasov (1990). Speaking about creolized texts, they imply the ones, "the pattern of which consists of two non-homogeneous parts (verbal lingual (speech) and non-verbal (belonging to other semiotic systems than the natural language)." (Sorokin Y. A., p.180 - 181). The bright examples of such texts are film texts, radio and TV broadcast texts, visual agitation and propaganda texts, billboards, advertising texts, etc.

The term "creolized texts" has been thoroughly investigated by E.E. Anisimova. Apart from describing various links between verbal and non-verbal components in a creolized text, the author highlights a different degree of their involvement into the text structure. Thus, the author puts forward the following classification of creolized texts based on the presence of the image and the nature of its connection with the verbal part: 1) texts with zero creolization (the image is not present), 2) texts with partial creolization and 3) texts with full creolization. This classification will serve as the basis of the current research. However, Anisimova's investigation has a limitation as it was conducted mainly based on the materials of Austrian German language billboards. 
Several publications have appeared in recent years confirming the fact that verbally and non-verbally transmitted information is perceived differently. Thus, Boiko claims that the "data which contains in a textual message is percieved only by $7 \%$, whereas voice characteristics facilitate digestion of $38 \%$ of data and the presence of a visual image significantly improves perception - up to 55\%” (Boiko, 2006). Along with this, other researchers remark that if verbally perceived information influences an individual in a rational way, usage of various paralinguistic means automatically transfers the process of perception to a subconscious level. Besides, visually perceived data, from the point of view of many scientists, causes more trust of the addressee: "What we see is quicker and easier perceived and causes less apprehension" (Vojtasek, 1981, 190).

Another aspect which is of vital importance when we speak about creolization is description of its paralinguistic means. This problem is widely studied by linguists with the primary focus on such paralinguistic tools of text formation as the colour and font, used in the text. Many scientists emphasize the symbolic function of the color, its ability to express abstract notions (Anisimova, 2003; Baskakov, 1967; Kondakov, 1990; Mironova, 1984; Padham, 1978). They claim that the colour is one of the most important components in the creolized text: it attracts attention of the addressee (thus performing an attraction function), allows to highlight the most significant elements in terms of the verbal component's meaning (meaning distinguishing function), and also influences a person's emotions (expressive function).

However, there are still few studies on the topic of creolized texts linguistics, in particular, there is a need in more practical investigation of such texts. For example, the specificity of creolized texts of the financial organizations' corporate sites has not been completely investigated; the kinds and functions of visual elements in their structure have not been fully described. Generally accepted approach to researching these texts has not been developed. Areas which require special attention include modern varieties of visual elements and the ways of their application on corporate business sites. In this context investigating creolization as an essential tool of communication and of attracting and retaining the addressee, demands extra researchers' attention.

\section{Methodology}

Creolized text analysis requires a complex approach, including investigation of verbal and non-verbal components, both separately and in their interaction.

The theoretical and methodological framework of the paper applies a complex approach, combining various research techniques. The key approach in the current study is structuralfunctional method, which is completed by a number of methodological approaches: system approach, communicative approach, discursivestylistic analysis, semantic analysis, the method of content-analysis. Let us give insights into each approach separately.

In frames of structural-functional approach a creolized text is viewed as a system, possessing a single structure, an integral unity of its verbal and non-verbal components functionality. Thanks to this technique it is possible to review each component separately, defining its specificity and along with this to track the processes of the components interaction. The method is highly productive also due to the opportunity to combine empirical observations with the theory of text and its function; therefore, it allows singling out certain regularities typical of creolized texts in the investigated material.

The necessity to justify theoretical statements using much empirical material required applying 
the method of content-analysis. Content-analysis is a widely spread method in textual analysis, which has many variations in different methodologies. It allows carrying out a quantitative and qualitative analysis of texts content with the purpose of further interpretation of the defined numerical regularities. Its primary focus is on the evaluation of quantitative distribution of words, phrases, the forms of the word and other analysis units (in our case it can be tables, slogans, charts, etc.) regarding the text. The result of such an analysis is generating data about the frequency, relative share, occurrence probability, etc. based on which it is possible to make a qualitative or quantitative conclusion depending on the target. Content analysis can be conducted using a wide range of methodologies. Thanks to this approach we have obtained data concerning the frequency of using visual elements in the corps of the investigated sites, their functions and ways of interaction with verbal elements.

Applied in complex, the above-mentioned scientific approaches make it possible to comprehend functioning of creolized texts on the corporate sites of financial organizations not only theoretically, but in certain distribution conditions.

\section{Discussion}

All 100 sites under investigation are the examples of creolized texts since the main sense bearers in them are verbal and non-verbal elements with the first ones being dominant. This conclusion can be made based on merely quantitative indicators: the English language to a certain degree is present in $100 \%$ of the analyzed material. It is worthwhile noting that the written text occupies on average about $70 \%$ of the site space, whereas graphically complicated inscriptions, in an unusual font or with enlargement, with colour or font highlighting (that is the text as a transition link between immediately verbal and non-verbal semiotics), can be observed in $30 \%$ of the analyzed material. Illustrations are found in all sites, however, in a smaller number - approximately in $35 \%$ of the analyzed material. Simultaneous usage of the written text and illustrations, that is representation of the verbal and non-verbal elements, occurs in $100 \%$ of cases.

It is necessary to mention, that the share and value of non-verbal components is less important in the investigated texts - it is determined by their participation in creating the bank's image, accentuating the most significant, from the site-makers' viewpoint, details, actualizing subconscious motifs.

The first stage of our analysis deals with investigating the texts from the point of view of theirhomogeneity-cohesion and interconnections between their verbal and iconic elements that is the degree of crealization. According to the described above Anisimova's creolization degrees classification, the sites analysis has revealed that all texts can be referred to the ones with full or partial crealization. No cases of zero creolization have been found. However, the level of creolizations depends to a large extent on the visual set made use of on the site.

Thus, the results obtained during the study show that there are 2 main visual sets utilized on the corporate sites of financial organizations. The first one is of specifically informative nature, the aim of its application is explaining information using tables, graphs and schemes. The second one is of visually-completing nature; its purpose is to express the slogan of a financial organization visually or to illustrate the service offered by the company.

In the first case it makes sense to speak about

\section{a high level of creolization (full creolization)}

since the non-verbal meaning is inseparably connected with its verbal expression. In such examples, formulas, symbolic pictures, graphs, 
tables, geometry figures and other visual elements are regarded as sense bearing components of the text which communicate its content. The most commonly met graphic element on the sites is the table, reflecting fluctuations of the currency exchange rate and fluctuations of other indexes for the current time period. For example, the most commonly met tables are those reflecting fluctuations of the DJIA index (Dow Jones Industrial Average) and NASDAQ (National Association of Securities Dealers Automated Quotation). Another frequently used illustrative way of visual presentation of the banks interest rates is a circular diagram, Pie Chart.

Graphs were found in 3\% of investigated sites, tables - in $4 \%$ and diagrams in $1 \%$. The results obtained indicate, from our point of view, that the choice of the data graphical representation depends only on the site-makers' policy. Graphs, tables and diagrams equally vividly and clearly reflect the dynamics of financial indicators fluctuations. They are commonly often used in the economic types of visual data representation for the client.

In all the above mentioned cases the role of the non-verbal text is merely informative; the verbal text serves as a linking and introductory element and constitutes a certain frame of "package material" for the visual image. The main content here is revealed by graphical components; an additional informative message is hidden in the image while the verbal text plays a less considerable role as if duplicating the content of the illustration. As a result, the impact on the recipient consciousness occurs primarily via the visual, but not textual channel.

The second type of the illustrative level is represented by pictures and photos. Investigating the structure of the crealized texts of this type has revealed that the role of the sense bearer is invariably performed here by the English language. Consequently, it seems justified to claim that these texts possess a partial degree of creolization, with the verbal part being relatively autonomous from the graphics and the image being an optional element of the text.

Another important finding made during the context analysis is connected with the text organization structure. It is necessary to note, that interaction of the image and verbal components of the sites in most cases has been found to be interdirected: the image illustrates the verbal components and the verbal elements, in their turn, interpret the image. Consequently, it is justified to speak about the principle of parallel development of verbal and non-verbal expressions applied for text organization. In other words, there is a simultaneous inclusion of verbal and non-verbal systems, which express the same meaning in parallel, each with its own means. Let us illustrate functioning of this principle in practice: for instance, on the site of the bank Capital One (www.capitalone. com) one can see a picture of a couple - a man and a woman. The woman is holding a credit card. The inscription inside explains - Popular for a reason. See the credit cards others are choosing. The message is clear: these cards are popular, they are chosen by many people. The link next to the image offers the site for the visitors to find more information. The text to the left is minimal and is used only to highlight a certain component of the sense. In the provided example such characteristics as popularity and convenience of the credit card are stressed, these very features are accentuated in the verbal part. This way it is evident that the meaning is expressed in parallel by verbal and non-verbal means. The results of the textcontent analysis enable us to say that such a mutually completing type of arranging verbal and non-verbal components in the texts of the analyzed creolized sites is widely spread and is present in $65 \%$ of all sites. 
Consequently, the above described finding provides ground for the assumption that the role of non-verbal elements in the contents is two-fold. As discovered, they can be either of a narrow informative character, applied to explain information or data with the help of tables, graphs, schemes, etc., or of illustrative-completing nature, the aim of which is to visually reflect the slogan or to illustrate the offered service. The basis of such a visual imagery is a logical relationship of transversion, when information represented in the image partially duplicates the information of the verbal text and completes it. Thus, in most cases non-verbally expressed information is, first and foremost, the element of the bank's image in the eyes of the customer. Its function is not primarily informative but accentuating. Illustrations and images are used to emphasize details, attract attention to certain fragments both in the design and in the informational part of the site.

Investigation of non-verbal meanings, represented in the form of illustrations in the corporate sites design, made it possible to single out the following four main types : 1) money (paper money and coins), 2) credit cards, 3) immovable assets (houses, cars, yachts, etc), 4) people. Let us examine these non-verbal meanings and their verbal expression in detail.

1) The image of money is widely represented in non-verbal variations in the investigated creolized texts (present in $40 \%$ of the material). Money is depicted as banknotes and coins. For example, in the site www.eastwestbank.com the monetary symbol $-\$$ is the center of attention. The first letter of the slogan "Safe Sound Secure" resembles the symbol \$. Furthermore, this association is supported by a package of dollar banknotes spread around. The given example vividly shows that non-verbal meaning is demonstrated verbally, with the letter $\mathrm{S}$ emphasized in the slogan which, consequently, causes strong associations with the dollar sign \$.
Another finding worth stressing is that the words, accompanying the pictures of money, possess a common seme "money" - savings, money, earn, maximize, reward, banking, etc. All these words with the semantic field "finance", together with the illustration of the money, contribute to creating a complete image and sense of money as a perception object.

2) In $20 \%$ of the studied material the core sense-making image is the one of a credit card. Credit cards found on the sites are all of a standard size with the only difference in the written message on the outer side. Each bank offers a credit card with its name on it - a kind of loyalty identity sign to the bank. Popularity and convenience of using credit cards is time-proven, therefore, banks strive to get a competitive advantage over others in this segment. For instance, American Express (www. americanexpress.com) offers additional benefits to its credit cards owners: "Enjoy the benefits of membership. Membership begins with the right card". The adjective "right" respectively implies choice of the card of this very bank.

A specific linguistic feature of creating sense by verbal means is connected with prevalence of the indicative mood in inscriptions and written messages to credit cards illustrations: enjoy, trade, explore, save, discover, get paid, get rewarded, learn, see, etc. They are all aimed at calling the potential customer to choose only their product.

3) Images of all kinds of immovable assets make up $50 \%$ of all images in the investigated material. First and foremost, we mean pictures of houses and apartments. Each second site places a picture of a house - it can be either a luxurious villa, or a detached house, or a sketchy image of an apartment. This way banks market their mortgage services. The images are followed by the such messages: Buying a home? Bankowned properties. Equal housing lender. Save on up-front mortgage fees with $M \& T$ checking. 
Seek our bank-owned property listings and find the home for you. Etc. Apart from information about mortgage terms, banks also offer mortgage consulting services, which can also be considered as their competitive advantage in retail market (www.emigrant.com):

If you are buying or refinancing a home, talk with one of our knowledgeable specialists who will customize a financing solution that's right for you.

4) Images of people - the most numerous group - were found on almost each corporate site of financial organizations (in 86\%).Within this group it is possible to define 2 smaller subgroups: illustration of family ties and demonstration of business partnership relations.

To the first group we can refer pictures of couples (man and woman), illustration of family ties (father and son, mother and daughter, grandparents surrounded by grandchildren, etc.). In most cases the words next to the image are direct speech of people depicted there. The personal pronoun WE is a clear signal testifying to this fact.

Associations, targeted to becaused by pictures in the recipients' minds, are usually expressed verbally in the nearby messages. For example in the site www.washingtonfederal.com there is a picture of a group of people, who are obviously friends, relatives and colleagues. Associations with the picture are expressed verbally by the following words in the inscription next to the image "tradition, families, generations, lasting". In this example the verbal sense is identical to the non-verbal meaning, therefore, it is possible to speak about parallel development of the text as a technique of building a creolized text structure.

Images of happy families (usually, mother, father and two kids - a standard American family) show that obtaining certain services from the bank is a key to a healthy and happy family life. On seeing such illustrations the potential client immediately draws the following association chain: family - bank - happiness. As a result, a financial organization acts as a certain "intermediary" between people and their aspirations. The same sense is communicated and duplicated verbally. Below are some typical comments to such illustrations: "The things we do for making life happier (www.53.com); With these new payment features, worry less and play more! (www.gemoney.com); More possibilities (www.midfirst.com) If I have dreams I want to finance. For the if in the life. East West Bank goes further and even promises to help in making the "American dream" come true for any family: "You can achieve the American Dream of Homeownership" (www.eastwestbank.com)

It is necessary to mention, that on the whole, all non-verbal senses are transparent and easily understandable thanks to some additional details present in the image. For example:

- a picture of man and woman at a computer illustrates the online trading service (computer is an emphasizing detail).

- a woman near an ATM machine - no fees for using the company ATMs.

- a woman talking over the phone paying bills over the telephone (Online Bill Pay \& Presentment).

However, it is worth noting that in some creolized texts the image of people in the pictures is not fully consistent with the verbally transmitted sense. For example, in the corporate site of BB\&T bank (www.bbt.com) there is a picture of an attractive smiling girl. It is possible to assume that the non-verbal component performs merely an aesthetic function. It is obvious that a picture of a beautiful girl contributes to creating a friendly, welcoming environment and a general positive image of the bank.

In some analyzed texts it is possible to speak about a combination of aims for using the visual elements in frames of the same site. 
Then in most cases the visual set has a double meaning - completing (pictures, photographs) and cognitive (tables, graphs). Without tables and graphs as creolized text elements, in contrast to photographs, the text loses its cognitive essence, that is, eventually, it loses its textuality. On the whole, the visual components in the form of illustrations, either decorative or cognitive, and the verbal elements create the single image of the creolized text as an object of verbal and visual communication. Verbal and visual components are linked on the content, compositional and language levels. The preference concerning the choice of a specific type of this connection is determined by the communicative aim and intention of the site creator, in particular, as well as by the functional purpose of the creolized text on the whole.

\section{Conclusion}

In conclusion it is worth going through the main points of the research. Preliminary research of information sources and available data suggests that the texts of corporate sites of financial organizations possess a number of characteristic features which allow us to refer them to creolized texts. The texts under analysis are built up combining such semiotic systems as the language and graphics. This paper presents an initial stage of searching for the answer to the questions if there is a link of visual and verbal elements in texts of corporate sites and what are the specifics of using visual elements in the investigated texts. In order to verify the validity of the statement regarding a close correlation of semiotic and non-semiotic means in the language, we checked for their presence, proportion and specificity in business discourse.

From the outcome of our investigation it is possible to conclude that the role of non-verbal components is double in terms of context. They are used in either explanatory purposes or as illustrations, visually demonstrating a certain product or service.

The paper has clearly shown that on most sites non-verbally expressed data is first and foremost, an element of the bank image in the customers' eyes. Illustrations are widely applied to underline details, attract attention to separate parts in the site design or in its content.

Visualization with the help of visual means of the verbal text leads to the fact that they are more metaphorical and emotional. A variety of expressive means (font, color) contribute to the emotional coloring of the site.

It is possible to distinguish basic non-verbal senses communicated in the texts of corporate sites. They can be divided into 4 main thematic groups (money, credit card, assets, people), each of them having the aim to arouse strong associations with the bank in the customers' mind. They are all supported and completed by lexical means with a corresponding sense-making seme.

To conclude, the issue of studying creolized texts in business discourse needs further multidirectional investigation. The areas of future analysis can lie within investigating the arsenal of stylistic means used to create a stylistic value of creolized texts in business discourse.

\section{References}

Alekseev, Yu.G.(1999). Vospriiatie kreolizovannogo teksta inoiazychnym retsipientom [Perception of a Creolized Text by a Foreign Recipient]. Penza, 8-10.

Anisimova, E.E. (2003). Lingvistika teksta i mezhkulturnaia kommunikatsiia (na materiale kreolizovannikh tekstov) [Text Linguistics and International Communications (on the Materials of Creolized Texts)]. Moscow, “Academia” Publ., 128 p. 
Berezin, V.M. (2003). Massovaya kommunikatsiia: sushchnost', kanaly, deistviia [Mass Communications: Essence, Channels, Actions]. Moscow, 162 p.

Bernatskaya, A.A. (2000). K probleme "kreolizatsii” teksta: istoriia i sovremennoe sostoianie [To the Problem of Text "Creolization”: History and Modern State]. Krasnoyarsk.

Boiko, M.A. (2006). Funktsionalnyi analiz sredstv sozdaniia obraza strany (na materiae nemetskikh politicheskikh kreolizovannih tekstov [Functional Analysis of the Means of Creation the Country Image (on the Material of German Political Creolized Texts)]. Voronezh .

Burkova, P. P. (2003). Tekst kulinarnogo retsepta kak lingvovizual'nyi phenomen [The Text of a Culinary Recipe as a Linguovisual Phenomenon], In Materiali Vserossijskoi nauchno-prakticheskoi konferentsii [Materials of All-Russian Scientific Practical Conference], Stavropol', SGU Publ.

Kamenskaya, O.L. (19960. Lingvistika na poroge XXI veka. [Linguistics at the Turn of the $21^{s t}$ Century]. Moscow.

Kirilov, A.G. (2006). Faktory vozdeistviya novostei v politicheskikh narrativakh na adresata [The Factors of News Impact on the Addressee in Political Narratives], In Sbornik statei XII Mezhdunarodnoi nauchno-prakticheskoi konferentsii [Proceedings of the Tenth International Practical Conference], Samara.

Sorokin, U.A., Tarasov, E.F. (1990). Kreolizovanniye teksty $i$ ikh kommunikativnaia funktsiia [Creolized Texts and Their Communicative Function]. Moscow.

Vojtasek, L. (1981). Psikhologiia politicheskij propagandy [Psychology of Political Propaganda]. Moscow.

Zenkova,A.Y.(2004).Vizualnaiametaphoravsotsial'no-politicheskomdiskurse:metodologicheskii aspect [Visual Metaphor in Social-Political Discourse: Methodological Aspect]. Yekaterinburg.

\title{
Соотношение вербального и невербального \\ компонентов в корпусе креолизованных \\ корпоративных сайтов финансовых организаций
}

\author{
Е.Е. Зуева \\ Высшая школа экономики \\ Нацииональный исследовательский университет \\ Россия, 603155, Нижний Новгород, \\ ул. Б. Печерская, 25/12
}

\begin{abstract}
В статье рассматривается природа гетерогенных семиотических систем - креолизованных текстов - и их основные характеристики. Особое внимание уделяется связи двух семиотических уровней креолизованного текста - вербальному и невербальному. Автор исследует роль и взаимосвязь данных элементов в структуре текста на примере корпоративных сайтов финансовых организаций. В результате исследования устанавливаются взаимосвязи вербально и визуально выраженных значений.
\end{abstract}

Ключевые слова: текст, знак, креолизованный, семиотика, коммуникация.

Научная специальность: philology. 